\title{
Nemesignis, a Replacement Name for Nemesis Furfaro \& Mariottini, 2021 (Mollusca, Gastropoda, Myrrhinidae), Preoccupied by Nemesis Risso, 1826 (Crustacea, Copepoda)
}

\author{
Giulia Furfaro $1, *\left(\mathbb{D}\right.$ and Paolo Mariottini ${ }^{2}$ (I) \\ 1 Department of Biological and Environmental Sciences and Technologies-DiSTeBA, University of Salento, \\ I-73100 Lecce, Italy \\ 2 Department of Science, University of Roma Tre, I-00146 Rome, Italy; paolo.mariottini@uniroma3.it \\ * Correspondence: giulia.furfaro@unisalento.it; Tel.: +39-0832-29-8660
}

check for updates

Citation: Furfaro, G.; Mariottini, P. Nemesignis, a Replacement Name for Nemesis Furfaro \& Mariottini, 2021 (Mollusca, Gastropoda, Myrrhinidae), Preoccupied by Nemesis Risso, 1826 (Crustacea, Copepoda). Life 2021, 11, 809. https://doi.org/10.3390/ life11080809

Academic Editors: Koichiro Tamura, Andrea Luchetti and Federico Plazzi

Received: 6 July 2021

Accepted: 4 August 2021

Published: 10 August 2021

Publisher's Note: MDPI stays neutral with regard to jurisdictional claims in published maps and institutional affiliations.

Copyright: (C) 2021 by the authors. Licensee MDPI, Basel, Switzerland. This article is an open access article distributed under the terms and conditions of the Creative Commons Attribution (CC BY) license (https:/ / creativecommons.org/licenses/by/ $4.0 /)$.

\begin{abstract}
The genus Nemesis Furfaro \& Mariottini, 2021, was recently introduced for an independent lineage of aeolid nudibranchs, and Dondice banyulensis Portmann \& Sandmeier, 1960, established as its type species. Anyway, the presence of a senior homonym, Nemesis Risso, 1826, was evidently missed. In fact, in 1826, Risso established this genus for a group of Copepoda (Arthropoda, Crustacea) and according to the Principle of Priority (ICZN) only the senior homonym may be used as a valid name. Therefore, a new replacement name is here proposed. Furthermore, the genus name Nanuca Er. Marcus, 1957, has priority over Dondice Er. Marcus, 1958 and consequently, the species in this clade should be classified under Nanuca, mostly as new combinations.
\end{abstract}

Keywords: ICZN; Dondice; homonym; Heterobranchia

\section{Introduction}

The genus Nemesis Furfaro \& Mariottini, 2021, was introduced based on evidence from a recent integrative systematic study [1] (Furfaro \& Mariottini, 2021) for an independent lineage of aeolid nudibranchs, and Dondice banyulensis Portmann \& Sandmeier, 1960 [2], was established as the type species. The newly identified lineage is currently monospecific and characterized by (i) the central cusp of the radular tooth that is not marked and a little longer than lateral denticles, (ii) the long distal and proximal deferent ducts of the male portion of the reproductive system and (iii) its inability to autotomise the cerata when stressed by possible predators. Just after the publication of our paper, Luigi Romani (Lucca, Italy) sent to us a letter (e-mail: 18.06.2021) where he noted that in our recent manuscript, we have evidently missed the existence of a senior homonym, Nemesis Risso, 1826 [3] (International Commission on Zoological Nomenclature - ICZN, 1999: Article 53.2) [4]. In fact, in 1826, Risso established this genus for a group of Copepoda (Arthropoda, Crustacea) and according to the Principle of Priority (ICZN, 1999: Article 52.3) [4], when two or more names are homonyms, only the senior may be used as a valid name. Therefore, a new replacement name is here proposed under the Article 60.3 of ICZN. Furthermore, Philippe Bouchet (Paris, France) pointed out to us that Nanuca Er. Marcus, 1957 [5], has priority over Dondice Er. Marcus, 1958 [6]. Consequently, the species in this clade should be classified under Nanuca, mostly as new combinations.

\section{Results and Discussion}

\section{Taxonomy}

Familia Myrrhinidae Bergh, 1905 [7]

Genus Nemesignis nom. nov. pro Nemesis Furfaro \& Mariottini 2021 (non Risso, 1826) urn:lsid:zoobank.org:pub:DEED49D6-F89B-4D68-A8A3-E1071197264C

Type species. Dondice banyulensis Portmann \& Sandmeier, 1960. 
Etymology. The genus name Nemesignis comes from the union of the Greek word Nemesis, that recalls the homonymous Greek goddess and her role of compensatory justice, with the Latin word Ignis, that is the fire that burns and blazes, linked to the fiery red colour of the type species of the genus.

Included species. N. banyulensis (Portmann \& Sandmeier, 1960).

Genus Nanuca Er. Marcus, 1957

Type species. Nanuca sebastiani Er. Marcus, 1957

= Dondice Er. Marcus, 1958 (type species: Caloria occidentalis Engel, 1925 [8])

Included species. Nanuca sebastiani Er. Marcus, 1957, Nanuca galaxiana (Millen \& Hermosillo, 2012) comb. nov. [9], N. occidentalis (Engel, 1925) comb. nov., N. parguerensis (Brandon \& Cutress, 1985) comb. nov. [10], N. trainitoi (Furfaro \& Mariottini, 2020) comb. nov. [11].

\section{Conclusions}

The presence of a senior homonym, which has priority over the recently stated Nemesis Furfaro \& Mariottini, 2021, made this latter genus name as invalid and invoked the need for a replacement name according to the rules of the ICZN. Therefore, Nemesignis nom. nov. is here proposed as the new replacement name, under the Article 60.3 of ICZN and consequently, Nemesignis banyulensis (Portmann \& Sandmeier, 1960) is its type species. Finally, since Nanuca Er. Marcus, 1957 has priority over Dondice Er. Marcus, 1958, the species in this clade should be classified under Nanuca, as Nanuca galaxiana (Millen \& Hermosillo, 2012) comb. nov., N. occidentalis (Engel, 1925) comb. nov., N. parguerensis (Brandon \& Cutress, 1985) comb. nov., N. trainitoi (Furfaro \& Mariottini, 2020) comb. nov.

Author Contributions: Conceptualization, G.F. and P.M.; validation, G.F. and P.M.; writing—original draft preparation, G.F.; writing - review and editing, P.M.; supervision, G.F. and P.M. Both authors have read and agreed to the published version of the manuscript.

Funding: This research received no external funding.

Institutional Review Board Statement: Not applicable.

Acknowledgments: We are grateful to Luigi Romani (Lucca, Italy) for alerting us of this homonymy and to Philippe Bouchet (Paris, France) for his suggestions. We thank the two anonymous reviewers that helped to improve the manuscript. Finally, we would like to deeply thank Marco Oliverio (Rome, Italy) for his constant help.

Conflicts of Interest: The authors declare no conflict of interest.

\section{References}

1. Furfaro, G.; Mariottini, P. Looking at the nudibranch family Myrrhinidae (Gastropoda, Heterobranchia) from a mitochondrial '2D folding structure' point of view. Life 2021, 11, 583. [CrossRef] [PubMed]

2. Portmann, A.; Sandmeier, E. Dondice banyulensis sp. nov. un Eolidien nouveau de la Méditerranée. Rev. Suisse Zool. 1960, 67, 159-168. [CrossRef]

3. Risso, A. Histoire Naturelle des Principales Productions de l'Europe Mèridionale et Particulièrement de Celles des Environs de Nice et des Alpes Maritimes; F.G. Levrault: Paris, France, 1826; Volume 5.

4. ICZN [International Commission on Zoological Nomenclature]. International Code of Zoological Nomenclature, 4th ed.; International Trust for Zoological Nomenclature: London, UK, 1999; p. xxix + 306.

5. Marcus, E. On opisthobranchia from Brazil (2). Zool. J. Linn. Soc. 1957, 43, 390-486. [CrossRef]

6. Marcus, E. On western Atlantic opisthobranchiate gastropods. Am. Mus. Novit. 1958, 1906, 1-82.

7. Bergh, L.S.R. Die Opisthobranchiata der Siboga-expedition. Siboga-Exped. 1905, 50, 1-248.

8. Engel, H. Westindische opisthobranchiate Mollusken. Bijdragen tot de kennis der fauna van Curaçao. Resultaten eener reis van Dr. C. J. van der Horst in 1920. Bijdr. Tot Dierkd. 1925, 24, 33-80. [CrossRef]

9. Millen, S.V.; Hermosillo, A. Three new species of aeolid nudibranchs (Opisthobranchia) from the Pacific coast of Mexico, Panama and the Indopacific, with a redescription and redesignation of a fourth species. Veliger 2012, 51, 145-164.

10. Brandon, M.; Cutress, C.E. A new Dondice (Opisthobranchia: Favorinidae) predator of Cassiopea in southwest Puerto Rico. Bull. Mar. Sci. 1985, 36, 139-144.

11. Furfaro, G.; Mariottini, P. A new Dondice Marcus Er. 1958 (Gastropoda: Nudibranchia) from the Mediterranean Sea reveals interesting insights into the phylogenetic history of a group of Facelinidae taxa. Zootaxa 2020, 4731, 1-22. [CrossRef] [PubMed] 